\title{
PDGFRB Gene Fusion Positive
}

National Cancer Institute

\section{Source}

National Cancer Institute. PDGFRB Gene Fusion Positive. NCI Thesaurus. Code C148118.

An indication that a PDGFRB fusion gene has been detected in a sample. 